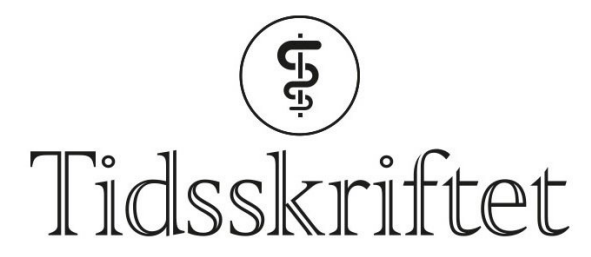

DEN NORSKE LEGEFORENING

\title{
Aldrende gliaceller kan forårsake nevrodegenerasjon
}

FRA ANDRE TIDSSKRIFTER

HAAKON B. BENESTAD

Universitetet i Oslo

Signaler fra astrocytter og mikroglia kan gi aggregering av tau-protein, som er involvert i utviklingen av nevrodegenerative sykdommer.

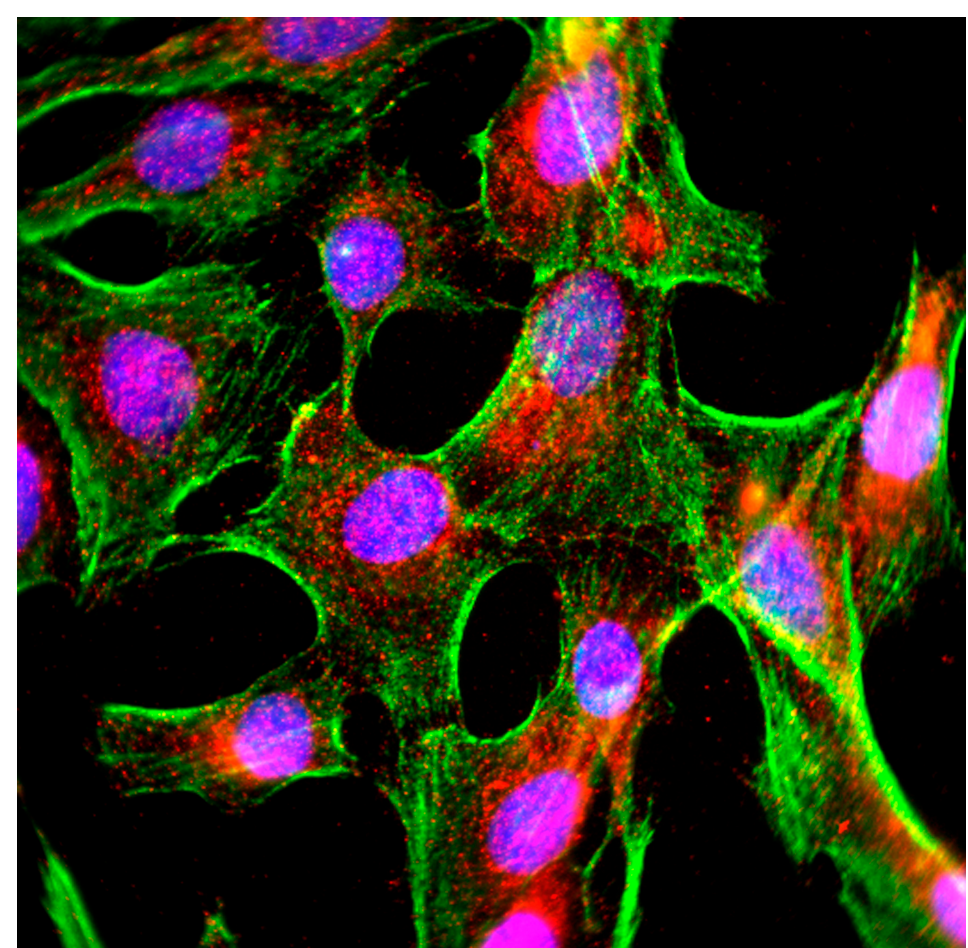

Dyrkede gliaceller som uttrykker tau-protein ( rødt). Blått = cellekjerner, grønt = aktinfibre.

Akkumulering av tau i hjernevev er knyttet til en rekke nevrodegenerative sykdommer. Illustrasjon:

Science Photo Library / NTB scanpix

En gammel celle stopper gjerne å dele seg og mister evnen til apoptose, men kan fortsette å skille ut proinflammatoriske molekyler og proteaser som kan skade friske naboceller. I en musemodell for hjernedegenerasjon induserte nevroner gliaceller i nærheten til å stoppe å dele seg, og gener som hemmer celledeling ble aktivert - gliacellene eldes (1). Eldede astrocytter og mikrogliaceller signaliserte tilbake til nevronene, slik at nevronene fosforylerte sin humane mutantversjon av proteinet tau, som så aggregerte og dannet nevrofibrillære floker som skadet cellene. 
Musemodellen ble validert ved å lage nye musestammer uten et antatt viktig ledd i signalkjeden, såkalt knock-out-mus. Uten dette leddet ble det ingen degenerasjon av kortikal- og hippocampusnevroner, med bevarte «kognitive» funksjoner hos musene. Tilførsel av navitoclax, som kunne redusere den alderstypiske sekresjonen, støttet de genmanipulatoriske forsøkene. Forskerne bak studien mener at denne musemodellen kan gi nye muligheter for behandling av nevrodegenerative lidelser hos mennesker ved å hemme signaler mellom nevroner og gliaceller.

- Det eksperimentelle oppsettet i denne studien gir oss et enda bedre bilde av kommunikasjonen mellom nevroner, astrocytter og mikrogliaceller ved nevrodegenerasjon, sier Tormod Fladby, som er professor ved Akerhus universitetssykehus.

- Dette er et svært interessant forskningsfelt som kan gi økt kunnskap om opprettholdelse av synapsefunksjon, plastisitet og læring ved aldring. Tau-relatert patologi er sentral ved Alzheimers sykdom, Parkinsons sykdom og andre nevrodegenerative sykdommer, sier Fladby, som påpeker at det har vært vanskelig å etablere kausale mekanismer som kan danne utgangspunkt for behandling. Forskerne bak studien mener at patologisk tauprotein er en direkte driver av nevrodegenerasjon, men det er fortsatt vanskelig å utelukke at inflammasjon spiller en rolle, sier Fladby.

\section{LITTERATUR:}

1. Bussian TJ, Aziz A, Meyer CF et al. Clearance of senescent glial cells prevents tau-dependent pathology and cognitive decline. Nature 2018; 562: 578-82. [PubMed][CrossRef]

Publisert: 11. februar 2019. Tidsskr Nor Legeforen. DOI: 10.4045/tidsskr.18.0971

(C) Tidsskrift for Den norske legeforening 2020. Lastet ned fra tidsskriftet.no 